\title{
Neither Morpheme nor Transleme ... Revisiting the Unit of Translation, Semiotically
}

\author{
Said M. Faiq \\ Department of Arabic \& Translation Studies \\ American University of Sharjah, United Arab Emirates
}

\begin{abstract}
Against the background of the disparities and disagreements across the spectrum of theory and practice about the unit of translation (UT), the purpose of this paper is to postulate that a semiotically - defined UT can fulfil the need of a concrete, viable and stable UT. Labelled textlet, the proposed UT is based on the semiotic triad of the sign, its meaning and its user. As a semiotic sign, textlet represents a particular meaning on the basis of similarity or dissimilarity to other textlets within the text. A textlet is a functional unit with an oppositional value defined by the communicative differences this opposition is capable of producing within texts.
\end{abstract}

Keywords: semiotics, textlet, semiotic triad, Unit of translation

Cite as: Faiq, S. M. (2017). Neither Morpheme nor Transleme ...Revisiting the Unit of Translation, Semiotically. Arab World English Journal for Translation \& Literary Studies, 1(1).

DOI: http://dx.doi.org/10.24093/awejtls/vol1no1.10 